\title{
Improve Student Learning Outcomes in Multiplication Learning Mixed Fractions Using Teams Games Tournament (TGT) Model.
}

\author{
Universitas Perjuangan Tasikmalaya \\ anisamardiyani.xak4@gmail.com
}

Anisa Mardiyani, Yusuf Suryana, Winarti Dwi Febriani

\section{Article History}

accepted 05/11/2020

approved $10 / 11 / 2020$

published 01/02/2021

\begin{abstract}
The problem in this study was the low student learning outcomes in mathematics learning the subject of multiplication of mixed fractions in class $V$. The purpose of this study was to see an increase in student learning outcomes in learning mixed fraction multiplication using the TGT learning model in class V SDN 2 Cigembor, Ciamis District, Regency. Ciamis. The population in the study were 30 grade students of SDN 2 Cigembor. The method used in this research is Classroom Action Research Methods (PTK) according to Kemmis and Mc. Taggart which consists of four stages: planning, implementing, observing, reflecting. This research was conducted in two cycles. The instruments used in this study were evaluation instruments, teacher performance instruments, and student activity instruments. Based on the results of the evaluation test data from cycle I to cycle II, it shows that in the first cycle the average student learning outcomes were 74.40 and learning completeness was $57 \%$, while in the second cycle the average student learning outcomes were 79.83 and completeness learn by $87 \%$. Based on the results of the research, it can be concluded that the use of the TGT learning model can improve student learning outcomes in the multiplication of mixed fractions in class V SDN 2 Cigembor, Ciamis District, Ciamis Regency, Academic Year 2019/2020.
\end{abstract}

Keywords: team game tournament, learning outcomes, mixed fractions, math

\begin{abstract}
Abstrak
Masalah dalam penelitian ini yaitu rendahnya hasil belajar siswa pada pembelajaran matematika pokok bahasan perkalian pecahan campuran di kelas V. Tujuan penelitian ini adalah untuk mengetahui peningkatan hasil belajar siswa pada pembelajaran perkalian pecahan campuran dengan menggunakan model pembelajaran TGT di kelas V SDN 2 Cigembor Kecamatan Ciamis Kabupaten Ciamis. Populasi dalam penelitian adalah siswa kelas V SDN 2 Cigembor sebanyak 30 orang. Metode yang digunakan dalam penelitian ini adalah Metode Penelitian Tindakan Kelas (PTK) menurut Kemmis and Mc. Taggart yang terdiri dari empat tahap yaitu : perencanaan, pelaksanaan, pengamatan, refleksi. Penelitian ini dilaksanakan dalam dua siklus. Instrumen yang digunakan dalam penelitian ini adalah Instrumen tes evaluasi, instrumen kinerja guru, dan instrument aktivitas siswa. Berdasarkan hasil data tes evaluasi dari siklus I hingga siklus II, menunjukkan bahwa pada siklus I rata-rata hasil belajar siswa sebesar 74,40 dan ketuntasan belajar sebesar $57 \%$, sedangkan pada siklus II rata-rata hasil belajar siswa sebesar 79,83 dan ketuntasan belajar sebesar $87 \%$. Berdasarkan hasil penelitian, maka dapat disimpulkan bahwa penggunaan model pembelajaran TGT dapat meningkatkan hasil belajar siswa pada perkalian pecahan campuran di kelas V SDN 2 Cigembor Kecamatan Ciamis Kabupaten Ciamis Tahun Ajaran 2019/2020.
\end{abstract}

Kata kunci: teams games tournament, hasil belajar, pecahan campuran, matematika

Social, Humanities, and Education Studies (SHEs): Conference Series https://jurnal.uns.ac.id/shes

p-ISSN 2620-9284

e-ISSN 2620-9292 


\section{PENDAHULUAN}

Tujuan pembelajaran matematika menurut Kurikulum 2013 (Kemendikbud, 2013) menekankan pada dimensi pedagogik modern dalam pembelajaran, yaitu menggunakan pendekatan scientific (ilmiah). Dalam pembelajaran matematika kegiatan yang dilakukan agar pembelajaran bermakna yaitu mengamati, menanya, mencoba, menalar, menyaji, dan mencipta. Selain itu dimaksudkan pula untuk mengembangkan kemampuan menggunakan matematika dalam pemecahan dan mengomunikasikan ide atau gagasan dengan menggunakan simbol, tabel, diagram, dan media lain. Menurut Ajun, Anita P (2013) "Pembelajaran matematika hendaknya dimulai dengan pengenalan masalah yang sesuai dengan situasi." Mengajukan masalah kontekstual, peserta didik secara bertahap dibimbing untuk menguasai konsep matematika.

Pada jenjang sekolah dasar, siswa diharapkan memiliki keterampilan berpikir logis, kritis, analitis, dan kreatif. Kompetensi tersebut diperlukan agar siswa memiliki kemampuan memperoleh, mengelola, dan memanfaatkan informasi yang didapatkan sehari-hari. Salah satu kompetensi dasar yang termuat dalam mata pelajaran matematika kelas $\mathrm{V}$ yaitu menjelaskan dan melakukan perkalian dan pembagian pecahan. Maka dari itu, diperlukan pembelajaran matematika yang memotivasi siswa untuk belajar secara mandiri maupun berkelompok agar aktif ketika pembelajaran sedang berlangsung. Pembelajaran yang dilakukan dengan kelompok-kelompok kecil dapat membantu siswa yang satu dengan yang lainnya. Di dalam kelas siswa dapat belajar bekerjasama melalui kerja kelompok agar tercipta interaksi positif yang dilakukan siswa satu dengan siswa lainnya. Trianto (2007) menyatakan bahwa pelajaran menggunakan model pembelajaran kooperatif memiliki ciri-ciri sebagai berikut : 1) siswa bekerja dalam kelompok untuk menuntaskan materi belajar; 2) kelompok yang dibentuk memiliki kemampuan tinggi, sedang, rendah; 3) anggota kelompok heterogen; 4) penghargaan lebih berorientasi pada kelompok dibanding individu. Pembelajaran kooperatif disusun dalam sebuah usaha untuk meningkatkan partisipasi siswa, memfasilitasi siswa dengan pengalaman sikap kepemimpinan dan membuat keputusan dalam kelompok, serta memberikan kesempatan kepada siswa untuk berinteraksi dan belajar bersama dengan siswa yang berbeda latar belakangnya.

Hasil evaluasi pembelajaran yang dilakukan oleh guru kelas, kemampuan siswa dalam pembelajaran matematika belum mencapai skor KKM. Demikian yang terjadi di kelas V SDN 2 Cigembor Kecamatan Ciamis, dari 30 siswa yang mengikuti ulangan matematika pada pokok bahasan Perkalian Pecahan Campuran hanya 14 siswa yang mencapai tingkat penguasaan materi $75 \%$. Berdasarkan hasil pengamatan, faktorfaktor yang menyebabkan rendahnya hasil belajar siswa yaitu, materi kurangnya kerjasama antar siswa, pembelajaran yang disampaikan tidak menarik perhatian siswa dalam proses pembelajaran, sehingga ada beberapa siswa yang kurang bisa memahami penjelasan guru, dan mereka malu untuk bertanya pada guru tentang halhal yang belum dipahami. Hidayat (2013) dan Suharni (2017), menemukan bahwa penggunaan model pembelajaran TGT dapat meningkatkan aktivitas dan hasil belajar siswa. Model pembelajaran kooperatif tipe TGT diharapakan mampu meningkatkan hasil belajar siswa dalam pembelajaran perkalian bilangan pecahan campuran.

Salah satu alternatif model pembelajaran yang efektif digunakan adalah model Teams Games Tournament (TGT). Slavin (2015:163) mendefinisikan TGT merupakan turnamen akademik, dan menggunakan kuis-kuis dan sistem skor kemajuan individu, 
dimana para siswa berlomba sebagai wakil tim mereka dengan anggota tim lain yang kinerja akademik sebelumnya setara mereka. Sehingga diharapkan selain mampu menjadi model pembelajaran matematika yang menyenangkan dan menarik siswa, model TGT diharapkan mampu meningkatkan hasil belajar dalam pembelajaran Perkalian Pecahan Campuran.

Berdasarkan latar belakang tersebut, peneliti telah melakukan penelitian pada pembelajaran Matematika kelas $\mathrm{V}$ di SDN 2 Cigembor Kecamatan Ciamis yang berjudul "Meningkatkan Hasil Belajar Siswa Pada Pembelajaran Perkalian Pecahan Campuran Menggunakan Model Pembelajaran Kooperatif tipe Teams Games Tournament (TGT)".

Tujuan penelitian ini, yaitu 1) untuk mendeskripsikan perencanaan pembelajaran dengan penggunaan model pembelajaran TGT untuk meningkatkan hasil belajar siswa pada pembelajaran Perkalian Pecahan Campuran di kelas V, 2) untuk mendeskripsikan proses pelaksanaan pembelajaran dengan penggunaan model pembelajaran TGT untuk meningkatkan hasil belajar siswa pada pembelajaran Perkalian Pecahan Campuran di kelas V, 3) untuk mendeskripsikan peningkatan hasil belajar siswa dengan penggunaan model pembelajaran TGT pada materi Perkalian Pecahan Campuran di kelas V.

\section{METODE}

Metode yang digunakan dalam penelitian ini adalah metode Penelitian Tindakan Kelas (PTK).

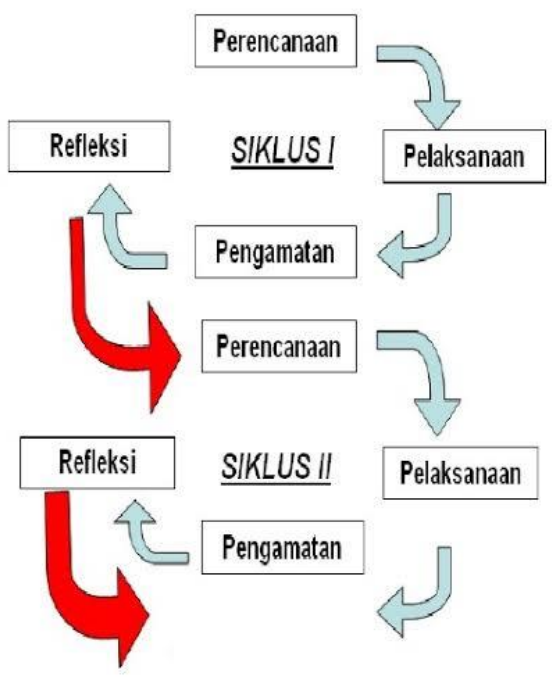

\section{Gambar 1. Tahap Penelitian}

Adapun tahap-tahap pada siklus I dan siklus II adalah sebagai berikut :

1) Perencanaan (Planning), merupakan langkah awal pada penelitian tindakan kelas. Adapun perencanaan pada penelitian ini adalah menyiapkan sumber belajar, menyiapkan silabus yang terkait dengan materi perkalian pecahan campuran, menyusun Rencana Pelaksanaan Pembelajaran (RPP), Menyusun kisi-kisi soal tes, menyusun soal tes beserta kunci jawaban, menyusun pedoman penskoran, 
menyiapkan dokumen-dokumen seperti daftar hadir, lembar kerja siswa, dan lainlain;

2) Pelaksanaan (Acting), pelaksanaan pembelajaran terdri dari 3 langkah kegiatan, yaitu kegiatan pendahuluan, inti, dan penutup;

3) Pengamatan (Observing),Pengamatan dilakukan pada saat pelaksanaan dalam proses pembelajaran menggunakan instrumen non tes berupa lembar observasi aktivitas siswa;

4) Refleksi (Reflecting) Refleksi dilakukan pada tiap akhir siklus berdasarkan hasil observasi selama proses pembelajaran berlangsung.

Sampel pada penelitian ini yaitu seluruh siswa Kelas $\mathrm{V}$ berjumlah 30 orang siswa. Sebelum melaksanakan penelitian, peneliti melakukan observasi terhadap pembelajaran matematika di kelas V SDN 2 Cigembor. Peneliti menemukan permasalahan yaitu rendahnya hasil belajar siswa pada materi Perkalian Pecahan Campuran. Dikarenakan proses pembelajaran belum terjalin dengan baik dan kurangnya kerjasama antar siswa, peneliti meyiapkan strategi perbaikan pembelajaran dengan menggunakan model pembelajaran TGT pada pembelajaran Perkalian Pecahan Campuran. Pembelajaran Perkalian Pecahan Campuran dengan menggunakan model pembelajaran TGT mengacu pada Rencana Pelaksanaan Pembelajaran (RPP) yang telah disiapkan oleh peneliti.

Pada penelitian ini terdapat tiga teknik pengumpulan data untuk memperoleh data-data empiris yang dapat digunakan untuk mencapai tujuan penelitian yaitu, teknik observasi, tes dan dokumentasi. 1) Teknik observasi digunakan untuk mengumpulkan data aktivitas siswa dan peneliti selama proses pembelajaran dengan menggunakan lembar aktivas peneliti, lembar observasi aktivitas siswa dan penskoran kesesuaian atau ketepatan RPP. Lembar observasi terhadap peneliti menggunakan instrumen APKG (adaptasi dari pedoman FKIP Kampus Universitas Perjuangan Tasikmalaya) dengan memperhatikan aktivitas peneliti dalam pengelolaan pembelajaran menggunakan model pembelajaran TGT diisi oleh observer (guru kelas/teman sejawat) pada setiap kegiatan pembelajaran berlangsung; 2) Tes yang digunakan dalam teknik pengumpulan data ini adalah tes tertulis untuk mengukur hasil belajar siswa pada materi pembelajaran Perkalian Pecahan Campura, pada akhir pembelajaran peneliti memberikan soal evaluasi setelah diterapkan model pembelajaran TGT; 3) Teknik dokumentasi bentuk dari dokumentasi pada penelitian ini antara lain RPP, silabus, daftar skor siswa, daftar kehadiran siswa, serta foto pada saat kegiatan pembelajaran menggunakan model pembelajaran TGT.

Penelitian ini dilaksanakan dalam 2 siklus. Penelitian ini dimulai pada tanggal 30 Juli 2020 sampai dengan 06 Agustus 2020. Peneliti menyiapkan instrumen penelitian diantaranya; RPP, LKS, Lembar soal evaluasi, instrumen observasi, dan menyiapkan semua yang dibutuhkan dalam pelaksanaan tindakan. Pelaksanaan tindakan perbaikan pembelajaran sesuai RPP yang dibuat peneliti dengan menggunakan model pembelajaran TGT pada materi Perkalian Pecahan Campuran. Proses pelaksanaan pembelajaran diamati oleh observer dan dinilai dengan menggunakan lembar observasi. Peneliti mengumpulkan data sesuai instrumen yang direncanakan. Peneliti merefleksi kegiatan penelitian untuk perbaikan siklus selanjutnya. Data yang diperoleh berupa hasil observasi dan hasil belajar siswa, kemudian diolah dan dianalisis menggunakan teknik penghitungan yang telah ditetapkan menurut para ahli. Data hasil 
analisis kemudian dipaparkan dalam bentuk tabel frekuensi dan grafik. Peneliti menarik kesimpulan berdasarkan kriteria keberhasilan yang ditetapkan. Peneliti melakukan verifikasi untuk melakukan tindakan perbaikan selanjutnya.

1. Peningkatan Hasil Belajar

\section{HASIL DAN PEMBAHASAN}

Adapun persentase peningkatan hasil belajar siswa dari siklus I ke siklus II, dapat dilihat pada tabel 1 sebagai berikut:

Tabel 1. Rekapitulasi Antar Siklus

\begin{tabular}{lcc}
\hline & Siklus I & Siklus II \\
\hline Rata-Rata & 74 & 80 \\
Persentase Ketuntasan & $57 \%$ & $87 \%$ \\
\hline
\end{tabular}

Terlihat bahwa siklus I ke siklus II terjadi peningkatan rata-rata kelas dari 74 menjadi 80 dengan ketuntasan yang juga terjadi peningkatan sebesar $30 \%$ yaitu dari $57 \%$ menjadi $87 \%$. Persentase ketuntasan kelas $\mathrm{V}$ yang dicapai pada siklus 1 ke siklus 2 tersebut telah mencapai standar yang ditentukan di SDN 2 Cigembor yaitu 75\% siswa tuntas KKM, serta skor rata-rata kelas juga telah mencapai KKM yang telah ditentukan yaitu 75 . Lebih jelasnya akan disajikan perbandingan jumlah siswa yang Tuntas dan Belum Tuntas siklus 1 dan siklus 2 dalam bentuk grafik berikut ini:

\section{Perbandingan Siklus I dan Siklus II}

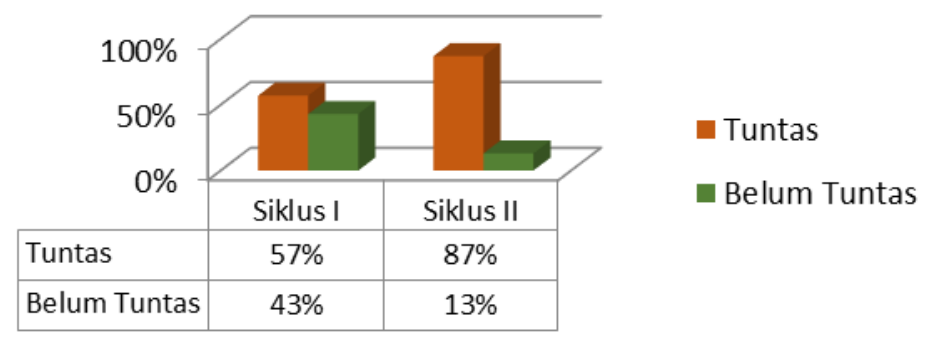

\section{Gambar 2. Perbandingan Antar Siklus}

2. Perencanaan Pembelajaran

Berikut adalah hasil observasi dalam pemenuhan aspek-aspek rencana pelaksanaan pembelajaran:

Tabel 2. Hasil Observasi RPP

\begin{tabular}{crc}
\hline Siklus & Rata-Rata & Persentase (\%) \\
\hline I & 3,32 & $83,03 \%$ \\
II & 3,61 & $90,17 \%$ \\
\hline
\end{tabular}

Berdasarkan tabel 3. Penilaian Rencana Pelaksanaan Pembelajaran pada materi Perkalian Pecahan Campuran menggunakan model pembelajaran TGT siklus I menunjukkan hasil yang "Baik". Hal ini didasarkan atas hasil observasi, masih ada indikator yang belum sesuai, sedangkan pada Siklus II telah memenuhi kriteria keberhasilan dengan kategori yang diperoleh "Sangat Baik." 
3. Pelaksanaan Pembelajaran berikut:

Hasil observasi pelaksanaan pembelajaran dirinci pada tabel 4. Sebagai

Tabel 3. Hasil Observasi Kinerja Guru dan Aktivitas Siswa

\begin{tabular}{lcccc}
\hline & \multicolumn{2}{c}{ Observasi Kinerja Guru } & \multicolumn{2}{c}{ Observasi Aktivitas Siswa } \\
Rata-Rata & Persentase (\%) & Rata-Rata & $\begin{array}{c}\text { Persentase } \\
\text { (\%) }\end{array}$ \\
\hline Siklus I & 3,25 & $81,25 \%$ & 2,7 & $68 \%$ \\
Siklus II & 3,64 & $91,07 \%$ & 3,3 & $80 \%$ \\
\hline
\end{tabular}

Hasil observasi dalam proses pelaksanaan pembelajaran pada materi Perkalian Pecahan Campuran menggunakan model pembelajaran TGT, pada siklus I dikatakan "Baik", tetapi masih ada indikator yang dirasa belum terpenuhi dengan baik. Sedangkan pada siklus II indikator telah terlaksana dengan baik, dengan kategori "Sangat Baik." Sedangkan hasil observasi aktivitas siswa dalam proses pembelajaran pada materi Perkalian Pecahan Campuran dengan menggunakan model pembelajaran TGT pada siklus I termasuk kategori "Kurang", karena siswa kurang memiliki keberanian untuk mengemukakan pendapatnya. Sedangkan siklus II hasil pengamatan aktivitas siswa termasuk pada kategori "Sangat Baik."

\section{Kegiatan Pembelajaran Siklus I dan Siklus II adalah sebagai berikut :}

Pendahuluan, Peneliti melalukan pembukaan dengan mengucapkan salam, mengkondisikan kelas, mengajak siswa berdoa, mengecek kehadiran siswa, melakukan apersepsi berupa tanya jawab, dan menyampaikan tujuan pembelajaran yang harus dicapai; Inti, Pada kegiatan ini, peneliti menyampikan bahwa pembelajaran akan menggunakan langkah-langkah model pembelajaran TGT meliputi penyajian kelas, belajar tim, game, turnamen, penghargaan kelompok. Peneliti memberikan soal kepada setiap kelompok untuk dikerjakan bersama dan diberikan waktu 10 menit. Kemudian perwakilan ketua kelompok duduk dimeja turnamen dan mendengarkan penjelasan mengenai aturan permainan. Lalu peneliti mengulas kembali beberapa pertanyaan yang tidak bisa dijawab oleh kelompok, dan menanyakan kepada siswa mengenai materi yang belum dipahami; Penutup, Peneliti dan siswa menyimpulkan materi bersama-sama. Kemudian peneliti sekilas menyampaikan materi yang akan dipelajari pada pertemuan selanjutnya. Dan peneliti memberika tes evalusai siklus I dan siklus II kepada seluruh siswa untuk mengetahui hasil belajarnya. Pembelajaran diakhiri dengan mengucapkan salam dan mengingatkan untuk tetap belajar.

Pada kegiatan pembelajaran siklus I peneliti hanya menjelaskan dan memberikan contoh-contoh soal yang berkaitan dengan perkalian pecahan campuran dengan menggunakan model pembelajaran TGT, sedangkan pada kegiatan pembelajaran siklus II peneliti lebih menekankan kerjasama antar kelompok untuk mengetahui peningkatan hasil belajar siswa pada pembelajaran perkalian pecahan campuran menggunakan model TGT.

\section{Peningkatan hasil belajar}

Terjadi peningkatan hasil belajar dari kedua siklus. Berdasarkan hasil analisis, siklus 1 ke siklus 2 terjadi peningkatan rata-rata kelas dari 74 menjadi 80 dengan ketuntasan sebesar $30 \%$ yaitu dari $57 \%$ menjadi $87 \%$. Persentase ketuntasan yang dicapai pada siklus 1 dan siklus 2 telah mencapai standar yang ditentukan di SDN 2 Cigembor yaitu siswa tuntas KKM (75). Persentase siswa yang tuntas pada siklus 1 diambil dari skor tes pada materi menentukan hasil perkalian pecahan campuran dan menyelesaikan masalah sehari-hari yang berkaitan dengan perkalian pecahan campuran siswa yang tuntas adalah $57 \%$ (17 siswa). Pada siklus 2 , presentase siswa yang tuntas diambil dari tes siklus 2 pada materi menentukan hasil perkalian pecahan 
campuran dan menyelesaikan masalah sehari-hari yang berkaitan dengan perkalian pecahan campuran adalah $87 \%$ (26 siswa). Kondisi tersebut diiringi dengan menurunya jumlah siswa yang Belum Tuntas mulai siklus I sebanyak 13 siswa, dan siklus II menjadi 4 siswa. Hasil tersebut telah memenuhi indikator kinerja pada penelitian ini yaitu $75 \%$ tuntas dengan KKM 75, sehingga pelaksanaan pembelajaran dihentikan pada siklus 2. Hal ini dikarekan sudah mencapai indikator kinerja yaitu ratarata kelas secara klasikal telah mencapai KKM, jumlah siswa yang mencapai KKM telah mengalami peningkatan, dan $75 \%$ siswa telah mencapai KKM yang ditentukan. Berdasarkan hasil peneletian, dapat disimpulkan bahwa hasil belajar siswa pada materi perkalian pecahan campuran menggunakan model TGT di Kelas V SDN 2 Cigembor Kecamatan Ciamis Kabupaten Ciamis Tahun Ajaran 2019/2020.

\section{SIMPULAN}

Berdasarkan hasil penelitian dan pembahasan yang telah diuraikan, maka dapat disimpulkan bahwa pembelajaran matematika pada materi perkalian pecahan campuran menggunakan model pembelajaran TGT dapat meningkatkan hasil belajar siswa kelas V SDN 2 Cigembor Kecamatan Ciamis Tahun Ajaran 2019/2020. Adapun peningkatan hasil belajar siswa ditinjau dari: 1) Rencana Pelaksanaan Pembelajaran pada materi perkalian pecahan campuran menggunakan model pembelajaran TGT, setiap siklus mengalami peningkatan. Siklus I termasuk kedalam kategori "Baik", sedangkan siklus II termasuk kedalam kategori "Sangat Baik"; 2) Pelaksanaan pembelajaran matematika materi perkalian pecahan campuran menggunakan model pembelajaran TGT, pada siklus I termasuk kedalam kategori "Baik" sedangkan siklus II termasuk kedalam kategori "Sangat Baik"; 3) Hasil belajar siswa dari pelaksaan siklus I dan siklus II dikatakan meningkat. Berdasarkan tes hasil evaluasi siklus I dan siklus II termasuk kategori "Baik".

\section{DAFTAR PUSTAKA}

Ajun, Anita P. 2013. Development Of Long And Square Learning Device With A Realistic Mathematical Approach Based On Bruner Theory For Student Classy VII SMP Negeri 1 Palopo. Jurnal Daya Matematis. Vol 1 No. 1, hal 71.

Hidayat Arif, Septianto. 2013. Peningkatan Minat Dan Hasil Belajar Pecahan Melalui Pembelajaran Teams Games Tournament Pada Siswa Kelas V Sekolah Dasar Negeri Keturen Kota Tegal. (Skripsi FKIP Universitas Negeri Semarang). Semarang.

Kemendikbud. 2013. Kerangka Dasar dan Struktur Kurikulum 2013. Jakarta: Kemendikbud.

Slavin, Robert E. 2015. Cooperative Learning. Bandung: Nusa Media.

Suharni, L. 2017. Penerapan Model Pembelajaran Kooperatif Tipe TGT Dalam Meningkatkan Hasil Belajar Matematika Siswa Kelas V B SDN 07 Baruga Kendari. Jurnal Penelitian. FKIP. Universitas Halu Oleo. Kendari. Wakapendik Vol 2. No. 4, hal 2-7.

Trianto. 2007. Model Pembelajaran Inovatif Berorientasi Konstruktivistik. Jakarta: Prestasi Pustaka. 